\title{
Prevention of Male Infertility by Early Detection of Congenital Hypogonadotropic Hypogonadism (CHH) Along with Sertoli Cell Dysfunction in Prepubertal and Transition Phase Starting from Neonatal Phase to Transition Phase - Time has Come
}

\author{
Kulvinder Kochar Kaur* \\ Scientific Director, Dr Kulvinder Kaur Centre for Human Reproduction, Jalandhar, \\ Punjab, India \\ *Corresponding Author: Kulvinder Kochar Kaur, Scientific Director, Dr Kulvinder \\ Kaur Centre for Human Reproduction, Jalandhar, Punjab, India.
}

DOI: $10.31080 /$ ASPE.2020.03.0213
Received: January 29, 2020;

Published: February 01, 2020

(C) All rights are reserved by Kulvinder

Kochar Kaur.
Earlier we have reviewed idiopathic hypogonadotropic hypogonadism ( $\mathrm{IHH})$ in detail and how congenital hypogonadotropic hypogonadism $(\mathrm{CHH})$, represents a rare problem that present secondary to reduced synthesis, secretion, or action of $\mathrm{Gn} \mathrm{RH}$, continues to be a difficult problem in paediatric endocrinology [1-4]. The prevalence of IHH IS $>$ in males and in them cryptorchidism is 3 fold $>$ in kallmann syndrome (KS) as compared to normosmic (nIHH) in spite of comparable testicular volume [5]. 10 Neonates or infants, all having bilateral cryptorchidism in intraabdominal/inguinal place as well as micropenis with no neonatal male minipuberty, got daily subcutaneous injections of Pergoviris (recombinant LH/FSH 75/150 IU for 3mths as part of the REMAP (REplacement of MAle mini Puberty) study where 10 yr follow up was attempted. By the end of therapy, median LH/FSH, both undetectable prior to therapy, went up to high normal levels of $4.45 \mathrm{IU} / \mathrm{L}$ as well as supranormal levels $83 \mathrm{IU} / \mathrm{L}$, respectively, median inhibin -b as well as antimullerian hormone (AMH) levels enhanced from below normal (27.8 and $1.54 \mathrm{ng} / \mathrm{mL}$, respectively) to normal values ( 365 as well as $150 \mathrm{ng} / \mathrm{mL}$, respectively), median testosterone escalated from just detected $(0.02 \mathrm{ng} / \mathrm{mL}$ to normal values $(3.3 \mathrm{ng} / \mathrm{mL})$. Stretched penile length enhanced from a median of 2 to $3.8 \mathrm{~cm}$. During treatment all testes descended to the scrotal position (by the end of 1 st mth in 3 cases, the 2 nd mth in 4 patients and the 3rd in 3 patients )measuring $1.5 \mathrm{ml}$ and, looking normal sonographically. Extra therapy with testosterone enanthate was administered to these infants. In 2 infants, one of 2 testes regressed in the low inguinal area; both infants got successful treatment surgically. Following 1 to $10 \mathrm{yrs}$ of follow up, all testes are still in scrotal position, having slightly regressed in size. Hence the proposed regimen simulates male minipuberty and treats successfully infants presenting with micropenis as well as cryptorchidism along with restoration of sertoli as well as leydig cell function as per Papadimitriou [6]. Hence from this it is quiet clear that early identification of $\mathrm{CHH}$ as well as isolated sertoli cell dysfunction needs to be identified in prepubertal as well as transition age. To allow a timely identification of isolated tubulopathy and SC dysfunction, the investigation should start in the prepubertal age and the transition phase [7]. The latter is the moment of transition from the pediatrician to the family doctor and hence one can avoid development of male infertility [8].

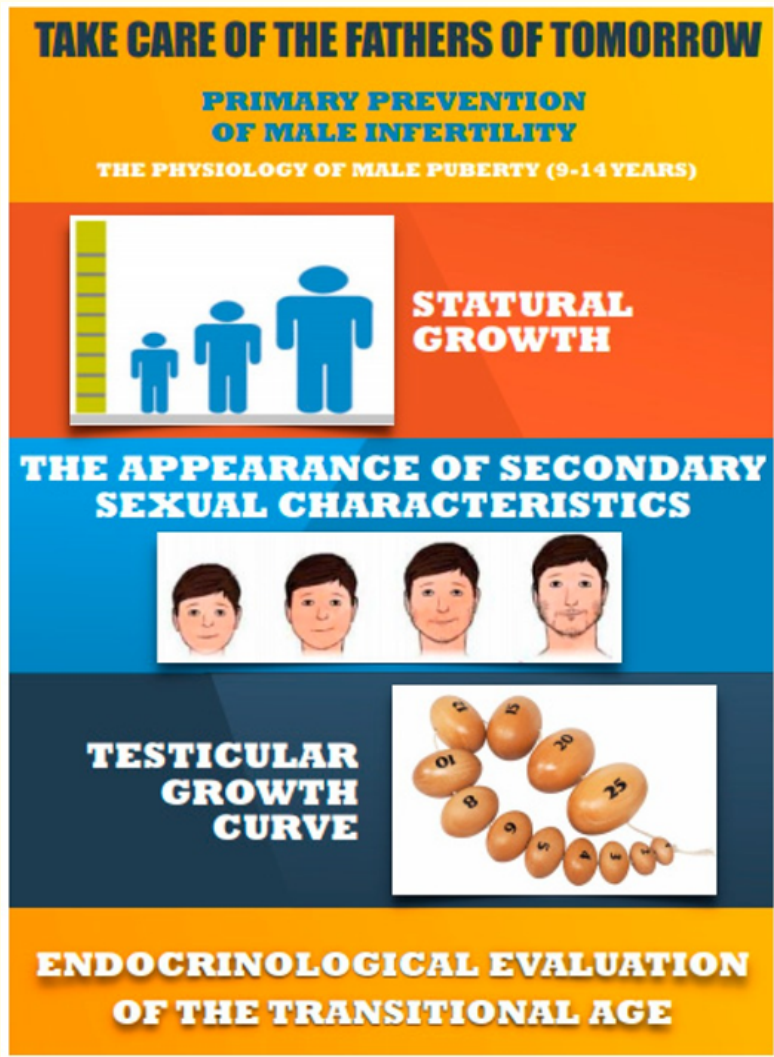

Figure 1: Primary prevention of male infertility. The importance of the testicular volume [8]. 
Identification of boys at risk for isolated primary testicular tubulopathy

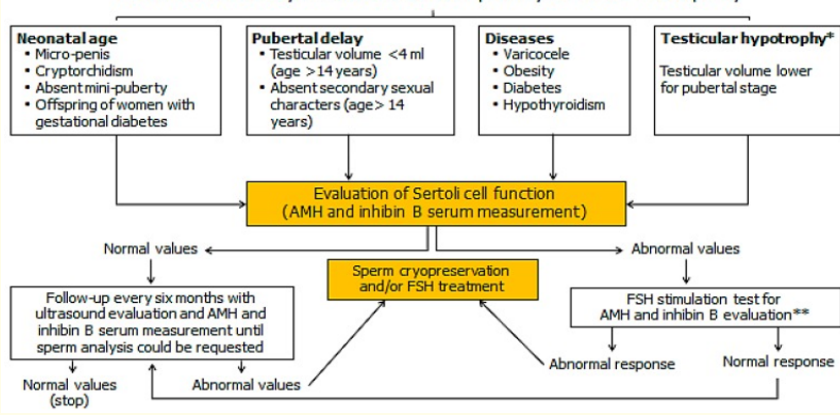

Figure 2: Flowchart proposed to help identify early testicular primary testicular tubulopathy inprepubertal and transitional age [8].

\section{Bibliography}

1. Boehm U., et al. "European Consensus Statement on congenital hypogonadotropic hypogonadism: pathogenesis, diagnosis and treatment". Nature Reviews Endocrinology 11.9 (2015): 547-564.

2. Young J., et al. "Clinical management of congenital hypogonadotropic hypogonadism”. Endocrine Review 40 (2019): 669-710.

3. Kulvinder Kochar Kaur., et al. "Idiopathic Hypogonadotropic Hypogonadism-An Update on the Aetiopathogenesis, Management of IHH in Both Males and Females-An Exhaustive Review". Advances in Sexual Medicine 6 (2016): 50-78.

4. Kulvinder Kochar Kaur., et al. "An Update on Aetiopathology, Various Genetic Causes and Management of Delayed PubertyA Minireview". Journal of Pediatrics and Neonatal Biology 4.1 (2019): 1-8.

5. Quinton R., et al. "Idiopathic gonadotrophin deficiency: genetic questions addressed through phenotypic characterization". Clinical Endocrinology (Oxf). 55.2 (2001): 163-174.

6. Papadimitriou DT., et al. "Replacement of Male Mini - Puberty". Journal of Endocrine Society 3.7 (2019): 1275-1282.

7. Young J., et al. "Testicular anti-mullerian hormone secretion is stimulated by recombinant human FSH in patients with congenital hypogonadotropic hypogonadism". The Journal of Clinical Endocrinology and Metabolism 90 (2005): 724-728.

8. La Vignera S., et al. "Early identification of isolated sertoli cell dysfunction in prepubertal and transition age: is it time?" Journal of Clinical Medicine 8 (2019): 636.

\section{Assets from publication with us}

- Prompt Acknowledgement after receiving the article

- Thorough Double blinded peer review

- Rapid Publication

- Issue of Publication Certificate

- High visibility of your Published work

Website: www.actascientific.com/

Submit Article: www.actascientific.com/submission.php Email us: editor@actascientific.com

Contact us: +919182824667

Citation: Kulvinder Kochar Kaur. "Prevention of Male Infertility by Early Detection of Congenital Hypogonadotropic Hypogonadism (CHH) Along with Sertoli Cell Dysfunction in Prepubertal and Transition Phase Starting from Neonatal Phase to Transition Phase - Time has Come". Acta Scientific Paediatrics 3.3 (2020): 01-02. 